\title{
HEPATITIS B VACCINATION COVERAGE AND POSTVACCINATION SEROLOGIC TESTING AMONG MEDICAL STUDENTS AT A PUBLIC UNIVERSITY IN BRAZIL
}

Eduardo Pernambuco de SOUZA(1) \& Marcelo de Souza TEIXEIRA(2)

\begin{abstract}
SUMMARY
The aim of this cross-sectional study was to determine the hepatitis B vaccination coverage among medical students at a public university in Rio de Janeiro, Brazil, and their compliance with the postvaccination serologic testing recommendations. Of the total of 858 students, 675 (78.7\%) participated in the study. Among the participants, $48.9 \%$ (95\% CI: $45.1 \%$ to $52.7 \%$ ) were vaccinated against hepatitis B (received $\geq 3$ doses of the vaccine), $31.6 \%$ were not (received 0,1 or 2 doses), and $19.6 \%$ did not know their vaccination status. Hepatitis B vaccination coverage increased from $26.0 \%$ among first-year students to $70.6 \%$ among sixth-year students while the prevalence of unknown vaccination status decreased from $39.7 \%$ among first-year students to $2.4 \%$ among sixth-year students. The frequency of unvaccinated students ranged from $23.7 \%$ among fifth-year students to $34.4 \%$ among first-year students. Only $34.8 \%$ of the vaccinated students performed the anti-HBs testing after vaccination. Among these medical students, we found a low adherence to the hepatitis B vaccination and to the postvaccination serologic testing. A comprehensive hepatitis B immunization program should be offered to students at this medical school.
\end{abstract}

KEYWORDS: Vaccination; Hepatitis B; Medical students.

\section{INTRODUCTION}

The hepatitis B virus infection can cause severe chronic liver disease, and is a public health problem in several countries ${ }^{31}$. In Brazil, approximately 14,000 cases of hepatitis B virus infection are reported every year and 120,343 cases were reported from 1999 to $2011^{3}$.

The hepatitis B virus can be transmitted through percutaneous or mucosal exposure to infected blood or body fluids, and health-care personnel are at risk of acquiring the disease from needle stick injuries or other types of occupational exposures ${ }^{9}$. This risk may be higher during the professional training period ${ }^{11,14,24,25}$. Therefore, the hepatitis B vaccination is strongly recommended for health-care personnel, including medical students and students of other health professions, and these individuals should perform the hepatitis B surface antibody (anti-HBs) testing 1-2 months after vaccination to evaluate the protective antibody response to the vaccine $e^{4,11}$.

In Brazil, students currently entering medical school were born before the implementation of universal hepatitis B vaccination of infants in $1998^{5}$. Vaccination of adolescents was recommended in $2001^{5}$, but this group is difficult to be reached by immunization programs, and studies have reported low vaccination coverage among Brazilian adolescents ${ }^{6,27}$. Consequently, students may enter medical school still unvaccinated against hepatitis B, and immunization programs at medical schools could contribute to vaccination of susceptible students. However, not all Brazilian medical schools have implemented such programs or student vaccination requirements. Therefore, it cannot be assumed a priori that most medical students are properly protected against hepatitis B. In fact, inadequate hepatitis B vaccination coverage has been observed among medical students and students of other health professions in Brazil $1^{7,8,12,29}$.

Information on vaccination coverage among medical students regarding the vaccines that are recommended for health-care personnel can contribute to the implementation of appropriate immunization efforts at medical schools. In this context, the aim of this study was to determine the hepatitis B vaccination coverage among medical students at a public university in Brazil, and their compliance with the postvaccination serologic testing recommendations.

\section{MATERIALS AND METHODS}

This cross-sectional study was conducted at the Universidade Federal do Estado do Rio de Janeiro Medical School. This medical school is one of the three public medical schools located in the city of Rio de Janeiro, Brazil, and offers a six-year course in medicine. Approximately one hundred and forty students are admitted each year. Students begin to have contact with patients and to perform

(1) Professor Adjunto de Pediatria, Escola de Medicina e Cirurgia, Universidade Federal do Estado do Rio de Janeiro (UNIRIO).

(2) Aluno do Curso de Graduação em Medicina, Escola de Medicina e Cirurgia. Universidade Federal do Estado do Rio de Janeiro (UNIRIO).

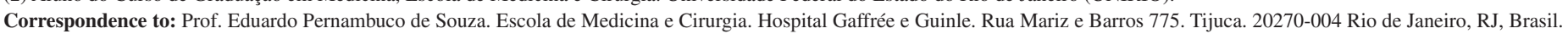
Tel: 21 22644159. E-mail: edupsz1@gmail.com 
some procedures, with risk of occupational exposures, in the second year of medical school. All medical students enrolled at this school in the second semester of 2010 were eligible to participate in this study. The invitation to participate was made during mandatory classes for students on different occasions.

A self-administered questionnaire was used to collect the following data: age, sex, and the student's current year in medical school; whether the student had been vaccinated against hepatitis B or not; the number of vaccine doses received by the student; whether the student had performed the anti-HBs testing after vaccination, and the approximate interval between the last vaccine dose and the anti-HBs testing.

In the present study, students were considered "vaccinated" against hepatitis B when they had received three or more doses of the vaccine, and were considered "unvaccinated" when they had not received the vaccine or had received only one or two vaccine doses. Vaccination status was considered "unknown" when students reported that they did not know if they had received the vaccine or they did not know the number of doses received.

The data were entered into an electronic database using double data entry, and a descriptive analysis was performed for all study variables. The 95\% confidence interval was calculated for the frequency of students who were "vaccinated" against hepatitis B. Vaccination status was compared across gender using the chi-square test. Analyses were performed with Epi Info (version 3.5.3 - 2011).

This study was approved by the ethics review committee of the Gaffrée e Guinle University Hospital at the Universidade Federal do Estado do Rio de Janeiro, and all students signed an informed consent before entering the study.

\section{RESULTS}

In the second half of 2010, 858 students were enrolled at the Universidade Federal do Estado do Rio de Janeiro Medical School, and $675(78.7 \%)$ responded to the survey questionnaire. Response rate ranged from $63.0 \%$ among sixth-year students to $92.4 \%$ among fourthyear students (Table 1). The mean age of the students was 22.8 years \pm 2.8 (range: 17 to 49 years): $59.7 \%$ were female students, and $40.3 \%$ were male students. Information on age was missing for eight students.

Of the total of 675 students, 330 students (48.9\%; 95\% CI: $45.1 \%$ to $52.7 \%$ ) were vaccinated against hepatitis B (received $\geq 3$ doses of the vaccine), $213(31.6 \%$ ) were unvaccinated (received zero, one or two doses of the vaccine), and 132 students (19.6\%) did not know their vaccination status (did not know if they had received the vaccine or did not know the number of vaccine doses received). Among the 213 students who were considered unvaccinated against hepatitis B, 80 students (37.6\%) did not receive any dose of the vaccine, 51 students $(23.9 \%)$ received one dose, and 82 students $(38.5 \%)$ received two doses.

The $\geq 3$-dose hepatitis B vaccination coverage increased from $26.0 \%$ among first-year students to $70.6 \%$ among sixth-year students. On the other hand, the prevalence of unknown vaccination status decreased from $39.7 \%$ among first-year students to $2.4 \%$ among sixth-year students. The frequency of unvaccinated students ranged from $23.7 \%$ among fifth-year students to $34.4 \%$ among first-year students (Table 1).

Among male students $(\mathrm{n}=272), 47.8 \%$ were vaccinated against hepatitis B, $32.4 \%$ were not, and $19.9 \%$ did not know their vaccination status. Among female students $(n=403), 49.6 \%$ were vaccinated, $31.0 \%$ were not, and $19.4 \%$ did not know their vaccination status $(p=0.89)$.

Of the total of 330 fully vaccinated students, 115 students (34.8\%) performed the anti-HBs testing after vaccination. Additionally, 15 students who had received one or two doses of the vaccine, and eight students who did not know the number of doses of the vaccine they had received also performed the anti-HBs testing after vaccination. Accordingly, a total of 138 students did the postvaccination serologic testing. Most students performed the anti-HBs testing one or more years after vaccination or did not know this interval (Table 2).

\section{DISCUSSION}

In this study we observed a low uptake of the hepatitis B vaccine among a group of Brazilian medical students since $31.6 \%$ of them were not fully vaccinated. The proportion of unvaccinated students may have even been underestimated because approximately $20 \%$ of the students

Table 1

Response rate and hepatitis B vaccination status according to year of medical school among Brazilian medical students

\begin{tabular}{|c|c|c|c|c|c|c|c|c|}
\hline \multirow{3}{*}{$\begin{array}{l}\text { Year of medical } \\
\text { school }\end{array}$} & \multirow{2}{*}{\multicolumn{2}{|c|}{ Response rate $(\mathrm{n}=858)$}} & \multicolumn{6}{|c|}{ Vaccination status $(n=675)$} \\
\hline & & & \multicolumn{2}{|c|}{ Vaccinated } & \multicolumn{2}{|c|}{ Unknown } & \multicolumn{2}{|c|}{ Unvaccinated } \\
\hline & $\mathrm{n} / \mathrm{N}$ & $\%$ & $\mathrm{n}$ & $\%$ & $\mathrm{n}$ & $\%$ & $\mathrm{n}$ & $\%$ \\
\hline First & $131 / 149$ & 87.9 & 34 & 26.0 & 52 & 39.7 & 45 & 34.4 \\
\hline Second & $102 / 145$ & 70.3 & 31 & 30.4 & 36 & 35.3 & 35 & 34.3 \\
\hline Third & $114 / 147$ & 77.6 & 58 & 50.9 & 19 & 16.7 & 37 & 32.5 \\
\hline Fourth & $146 / 158$ & 92.4 & 81 & 55.5 & 15 & 10.3 & 50 & 34.2 \\
\hline Fifth & $97 / 124$ & 78.2 & 66 & 68.0 & 8 & 8.2 & 23 & 23.7 \\
\hline Sixth & $85 / 135$ & 63.0 & 60 & 70.6 & 2 & 2.4 & 23 & 27.1 \\
\hline Total & $675 / 858$ & 78.7 & 330 & 48.9 & 132 & 19.6 & 213 & 31.6 \\
\hline
\end{tabular}




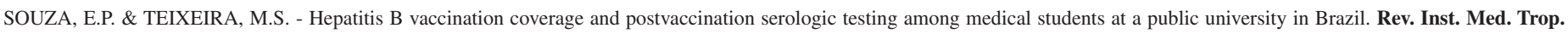
Sao Paulo, 56(4): 307-11, 2014.

Table 2

Approximate interval between the last dose of the hepatitis B vaccine and the anti-HBs testing among Brazilian medical students $(\mathrm{n}=138)$

\begin{tabular}{lcc}
\hline \multirow{2}{*}{$\begin{array}{l}\text { Approximate interval between the last dose of the } \\
\text { vaccine and the anti-HBs testing }\end{array}$} & \multicolumn{2}{c}{ Students } \\
\cline { 2 - 3 } & $\mathrm{n}$ & $\%$ \\
\hline < 1 year & 23 & 16.7 \\
1-4 years & 34 & 24.6 \\
Z 5 years & 19 & 13.8 \\
Unknown & 58 & 42.0 \\
Missing & 4 & 2.9 \\
\hline
\end{tabular}

did not know their vaccination status, and some of these students could be unvaccinated. In addition and perhaps more importantly, among students attending the final year of medical school, hepatitis B vaccination coverage was only $70.6 \%$, and in this group $2.4 \%$ of the students did not know their vaccination status.

Few studies have investigated the hepatitis B vaccination coverage among medical students in Brazil ${ }^{1,7,12,24}$. One study reported a vaccination coverage of $71.3 \%$ among fifth-year medical students ${ }^{12}$ and this result was similar to that observed among our students who were in the same year of medical school (68.0\%). In another study, a higher vaccination coverage and of $86.8 \%$ was observed among second- to sixth-year medical students ${ }^{24}$. At a medical school in the state of Santa Catarina, Brazil only $53.8 \%$ of the students were vaccinated against hepatitis B, but in this study the number of vaccine doses was not determined, and the vaccination status was unknown for approximately $43 \%$ of the students ${ }^{1}$.

Other studies conducted in Brazil assessed the hepatitis B vaccination coverage among different groups of health-care personnel, with varying results. As among our students, vaccine uptake was suboptimal in some of these groups ${ }^{2,8,17,28-30}$. Vaccination coverage of less than $80 \%$ has been reported among physicians in two Brazilian cities ${ }^{17,28}$, residents in pediatrics $^{30}$, dental students ${ }^{8,29}$, and health-care workers in the city of Belo Horizonte $^{2}$. Among health-care students, including medical students, who were exposed to biological material in São Paulo-Brazil, only $77.1 \%$ of them had received three or more doses of the vaccine ${ }^{18}$. On the other hand, vaccination coverage of more than $90 \%$ was observed among dentists ${ }^{16}$ and physicians ${ }^{2,15}$ in some Brazilian cities. However, one must be careful to compare the results of these studies because different methods were used to assess the vaccination status (self-reported vaccination status or vaccination records), and in some studies it is unclear whether vaccinated individuals were only those who had received the 3 -dose vaccine series or were individuals who had received at least one dose of the vaccine. In other countries, including the US, optimal hepatitis $B$ vaccination coverage among health-care personnel has not been achieved either ${ }^{22}$.

Interestingly, we observed that hepatitis B vaccination coverage increased progressively from $26.0 \%$ among first-year students to $70.6 \%$ among sixth-year students while the prevalence of unknown vaccination status decreased from $39.7 \%$ to $2.4 \%$. Since this study was not prospective and we did not investigate when students were vaccinated, whether before or during the medical course, we cannot explain these findings with certainty. Perhaps, students attending different years of the medical course had already different vaccination status when they were admitted to medical school. However, during the medical course students have several opportunities to learn about the importance of being vaccinated against hepatitis B and of knowing their vaccination status. The acquisition of this knowledge might have contributed to a higher vaccination coverage and a lower prevalence of unknown vaccination status among students attending the last years of the medical course. Nevertheless, in each year of this medical course, approximately a quarter to a third of the students had not received the 3-dose hepatitis B vaccine series.

In Brazil, the hepatitis B vaccine is available free of charge to healthcare personal, including medical students, at a large network of healthcare facilities. In the present study, we did not investigate the reasons that could eventually explain why students were not vaccinated. However, the medical school where this study was conducted does not have a student immunization program or vaccination requirements, and this might have contributed to the low hepatitis B vaccine uptake among our study group. In this regard, a higher hepatitis B vaccination coverage was reported among Brazilian medical students to whom an immunization program was offered at their medical school ${ }^{24}$.

Exposure to blood or body fluids potentially contaminated with hepatitis B virus is common among medical students ${ }^{12,14,18,24-26}$. Moreover, in Brazil, the number of confirmed cases of hepatitis B infection is higher among young adults than among other age groups, and most cases of the disease are probably acquired through sexual contact ${ }^{3}$. The majority of medical students are young adults, and thus unvaccinated medical students may be at risk of acquiring the disease not only through occupational exposures but also by sexual contact.

In the present study, only $34.8 \%$ of the vaccinated students performed the anti-HBs testing after vaccination to determine their antibody response to the vaccine. However, based on this result we cannot conclude whether or not the students complied with the postvaccination serologic testing recommendations for health-care personnel because we did not investigate when students were vaccinated, and the anti-HBs testing was not mandatory for those students vaccinated in the past, before entering medical school ${ }^{11}$. In fact, different recommendations would have been acceptable for students vaccinated before entering medical school: not to perform the anti-HBs testing unless they were exposed to blood or body fluids ${ }^{11}$ or to perform the testing and eventually administer a booster dose of the vaccine to those with anti-HBs concentrations of less than 10 $\mathrm{mIU} / \mathrm{mL}^{4,10}$. On the other hand, students vaccinated during the medical course should have performed the anti-HBs testing 1-2 months after the last dose of the hepatitis B vaccine series ${ }^{4,11}$. Nevertheless, we can conclude that the response to the vaccine was unknown for most of the vaccinated students, and this can be an issue in some circumstances. When the response to the vaccine is unknown, the management of health-care personnel potentially exposed to hepatitis B virus is more complex, and in this context the anti-HBs testing should be performed immediately. However, in some settings in Brazil, the anti-HBs testing or its results may not be readily available. Other studies conducted in Brazil also reported that a significant proportion (approximately 32\% to 48\%) of health-care personnel who were vaccinated against hepatitis B did not perform the postvaccination serologic testing ${ }^{15,24,28}$.

In addition, most students performed the anti-HBs testing one or more years after the last dose of the vaccine or did not know how long 


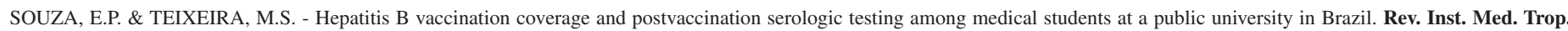
Sao Paulo, 56(4): 307-11, 2014.

after vaccination the testing had been performed. The anti-HBs testing performed years after vaccination is not adequate for evaluating the response to the vaccine because anti-HBs concentrations decline over time. However, individuals who responded to the 3-dose vaccine series remain protected even if their anti-HBs concentration declines to below $10 \mathrm{mIU} / \mathrm{mL}$ due to immune memory ${ }^{23}$. In this respect, among healthcare students in Taiwan, who were vaccinated during infancy with a recombinant hepatitis $B$ vaccine, a study reported that after 16 years only $33 \%$ had protective levels of anti-HBs, but $95.9 \%$ of the anti-HBs negative students achieved protective levels of anti-HBs after a booster dose of the vaccine, indicating the presence of immune memory ${ }^{20}$. Perhaps, in the present study, students performed the anti-HBs testing years after vaccination because they were vaccinated in the past and desire to know whether they were protected against hepatitis B or not. In this context, to perform the anti-HBs testing is an acceptable option as far as the test results are correctly interpreted and the students are properly counseled.

In Brazil, universal hepatitis $B$ vaccination of infants was implemented in 1998, and vaccination of adolescents younger than 20 years of age was recommended in $2001^{5}$. A study conducted among Brazilian medical students in 2009 reported that approximately $60 \%$ of the students were vaccinated against hepatitis B before entering medical $\mathrm{school}^{24}$. In the future, more students will possibly enter medical school already vaccinated against hepatitis B and medical schools will have to decide whether to recommend the anti-HBs testing for all students or only for those who have an occupational exposure.

This study has some limitations. Assessment of vaccine uptake was based on student self-reported vaccination status, and misclassifications might have occurred. However, the use of vaccination records to assess vaccination status can also lead to misclassification of individuals with missing vaccination records. Among some groups, missing or unavailable vaccination records are not uncommon ${ }^{15,30}$, and a study conducted among Brazilian nursing and medical students reported that, after several attempts, only $11 \%$ of the students provided their vaccination cards ${ }^{7}$. Furthermore, we could have had more accurate and complete information on the postvaccination serologic testing if we had determined when students were vaccinated, whether at medical school or before, and if we had reviewed the laboratory reports for the anti-HBs testing. However, laboratory reports are not easily available. Some fifth- and sixth-year students answered the study questionnaire later than the other students. Consequently, they had more time to clarify their vaccination status, and to complete their hepatitis B vaccination schedule, perhaps influenced by their knowledge about the survey. This might have contributed to increase the vaccination coverage in this group. On the other hand, there are few studies reporting on hepatitis B vaccination coverage among Brazilian medical students, and the present study, despite its limitations, can provide additional information regarding health-care students compliance with the recommended vaccines in Brazil.

In conclusion, in the present study we found a low uptake of the hepatitis B vaccine among a group of Brazilian medical students, despite the wide availability of the vaccine. In addition, most vaccinated students did not perform the postvaccination serologic testing and thus, their response to the vaccine was unknown. It is well recognized that medical students have a high risk of being exposed to blood and body fluids potentially contaminated with hepatitis B virus, and hepatitis B vaccination is mandatory or recommended for these students in several countries $^{11,13,19,21}$. Accordingly, this medical school should urgently consider to implement a comprehensive student immunization program against hepatitis B, which may contribute to improve students' adherence to vaccination. This program should be offered early in the medical course and provide not only vaccination but also screening and follow up. Furthermore, education on prevention and management of occupational exposures should be also provided to these students, and counseling should be immediately available in case of exposure. Finally, continuous surveillance of hepatitis B vaccination coverage among medical students should be undertaken in Brazil, especially at those medical schools which do not have student vaccination requirements.

\section{RESUMO}

\section{Cobertura vacinal para a hepatite B e teste sorológico pós-vacinal entre estudantes de medicina de universidade pública no Brasil}

O objetivo deste estudo transversal foi determinar a cobertura vacinal para a hepatite $\mathrm{B}$ entre estudantes de medicina de uma universidade pública no Rio de Janeiro, Brasil e a sua adesão às recomendações sobre o teste sorológico pós-vacinal. De um total de 858 estudantes, 675 $(78,7 \%)$ participaram do estudo. Entre os participantes, $48,9 \%$ (IC de 95\%: $45,1 \%$ a $52,7 \%$ ) eram vacinados contra a hepatite B (receberam $\geq 3$ doses da vacina), 31,6\% não eram (receberam zero, uma ou duas doses) e $19,6 \%$ não sabiam o seu status vacinal. A cobertura vacinal para a hepatite B aumentou de $26,0 \%$ entre os estudantes do primeiro ano para $70,6 \%$ entre os estudantes do sexto ano, enquanto a prevalência de status vacinal ignorado diminuiu de $39,7 \%$ entre os estudantes do primeiro ano para $2,4 \%$ entre os estudantes do sexto ano. A frequência de estudantes não vacinados variou de $23,7 \%$ entre os estudantes do quinto ano a $34,4 \%$ entre os estudantes do primeiro ano. Apenas $34,8 \%$ dos estudantes vacinados realizaram o teste anti-HBs após a vacinação. Entre esses estudantes de medicina encontramos uma baixa adesão à vacinação contra a hepatite $\mathrm{B}$ e ao teste sorológico pós-vacinal. Um amplo programa de imunização contra a hepatite B deveria ser oferecido aos estudantes, nessa escola médica.

\section{AUTHOR CONTRIBUTIONS}

Both authors participated in all study phases. EPS coordinated the study.

\section{COMPETING INTERESTS}

The authors declare that they have no competing interests.

\section{REFERENCES}

1. Arent PM, Cunha L, Freitas PF. Situação vacinal dos estudantes de medicina da Universidade do Sul de Santa Catarina no período prévio ao internato. Rev Ciênc Méd. 2009;18:13-20.

2. Assunção AA, Araújo TM, Ribeiro RB, Oliveira SV. Hepatitis B vaccination and occupation exposure in the healthcare sector in Belo Horizonte, Minas Gerais. Rev Saúde Pública. 2012;46:665-73.

3. Brasil. Ministério da Saúde. Secretaria de Vigilância em Saúde. Boletim Epidemiológico Hepatites Virais (versão preliminar). 2012; Ano III ( ${ }^{\circ}$ 01). [cited 2012 Sep 12]. Available from: http://www.aids.gov.br/publicacao/2012/boletim_epidemiologico_ de_hepatites_virais_2012 

Sao Paulo, 56(4): 307-11, 2014.

4. Brasil. Ministério da Saúde. Secretaria de Vigilância em Saúde. Manual dos Centros de Referência para imunobiológicos especiais. $3^{\mathrm{a}}$ ed. 2006. [cited 2011 Nov 19].Available from: http://portal.saude.gov.br/portal/arquivos/pdf/livro_cries_3ed.pdf

5. Brasil. Ministério da Saúde. Secretaria de Vigilância em Saúde. Programa Nacional de Imunizações - 30 anos. 2003. [cited 2012 Oct 9]. Available from: http://portal.saude. gov.br/portal/arquivos/pdf/livro_30_anos_pni.pdf

6. Bueno MM, Matijasevich A. Avaliação da cobertura vacinal contra hepatite B nos menores de 20 anos em municípios do Estado do Rio Grande do Sul, Brasil. Epidemiol Serv Saúde. 2011;20:345-54.

7. Cabrera EMS, Merege CES. Inquérito vacinal de alunos da graduação em medicina e enfermagem da Faculdade de Medicina de São José do Rio Preto (SP, Brasil) nos anos de 2006 e 2007 e suas possíveis implicações na atuação discente. Ciênc Saúde Coletiva. 2011;16:547-52.

8. Carneiro GGVS, Cangussu MCT. Prevalência presumível, cobertura vacinal, conhecimentos e atitudes relativos à hepatite $\mathrm{B}$ em graduandos de Odontologia da Universidade Federal da Bahia. Rev Odontol UNESP. 2009;38:7-13.

9. Centers for Disease Control and Prevention. Updated U.S. Public Health Service guidelines for the management of occupational exposures to $\mathrm{HBV}, \mathrm{HCV}$, and $\mathrm{HIV}$ and recommendations for postexposure prophylaxis. MMWR Recomm Rep. 2001;50(RR$11): 1-52$.

10. Centers for Disease Control and Prevention (CDC). Ask the Experts: Hepatitis B. [cited 2012 Oct 10]. Available from: http://www.cdc.gov/vaccines/vpd-vac/hepb/default. htm

11. Centers for Disease Control and Prevention (CDC). Immunization of health-care personnel: recommendations of the Advisory Committee on Immunization Practices (ACIP). MMWR Recomm Rep. 2011;60(RR-7):1-45.

12. Chehuen Neto JA, Sirimarco MT, Leite ICG, Gonçalves MPC, Delgado AAA, Camilo GB, et al. Situação vacinal dos discentes da Faculdade de Medicina da UFJF-MG. Rev Bras Educ Med. 2010;34:270-7.

13. De Schryver A, Claesen B, Meheus A, van Sprundel M, Francois G. European survey of hepatitis B vaccination policies for healthcare workers. Eur J Public Health. 2011;21:338-43.

14. Deisenhammer S, Radon K, Nowak D, Reichert J. Needlestick injuries during medical training. J Hosp Infect. 2006;63:263-7.

15. Dinelli MI, Moreira TD, Paulino ER, da Rocha MC, Graciani FB, de Moraes-Pinto MI. Immune status and risk perception of acquisition of vaccine preventable diseases among health care workers. Am J Infect Control. 2009;37:858-60.

16. Ferreira RC, Guimaraes AL, Pereira RD, Andrade RM, Xavier RP, Martins AM. Hepatitis B vaccination and associated factors among dentists. Rev Bras Epidemiol. 2012;15:315-23

17. Garcia LP, Facchini LA. Vacinação contra a hepatite B entre trabalhadores da atenção básica à saúde. Cad Saude Publica. 2008;24:1130-40.

18. Gir E, Netto JC, Malaguti SE, Canini SR, Hayashida M, Machado AA. Accidents with biological material and immunization against hepatitis B among students from the health area. Rev Lat Am Enfermagem. 2008;16:401-6.
19. Government of South Australia, Immunisation Section. Communicable Disease Control Branch. Immunisation Guidelines for Health Care Workers in South Australia. 2010 [cited 2013 Mar 17]. Available from: http://www.health.sa.gov.au/pehs/Immunisation/ hcwguidelines-pehs-sahealth-1004.pdf

20. Lin CC, Yang CY, Shih CT, Chen BH, Huang YL. Waning immunity and booster responses in nursing and medical technology students who had received plasma-derived or recombinant hepatitis B vaccine during infancy. Am J Infect Control. 2011;39:408-14.

21. Lindley MC, Lorick SA, Spinner JR, Krull AR, Mootrey GT, Ahmed F, et al. Student vaccination requirements of U.S. health professional schools: a survey. Ann Intern Med. 2011;154:391-400.

22. Lu PJ, Byrd KK, Murphy TV, Weinbaum C. Hepatitis B vaccination coverage among high-risk adults 18-49 years, U.S., 2009. Vaccine. 2011;29:7049-57.

23. Mast EE, Weinbaum CM, Fiore AE, Alter MJ, Bell BP, Finelli L, et al. A comprehensive immunization strategy to eliminate transmission of hepatitis B virus infection in the United States: recommendations of the Advisory Committee on Immunization Practices (ACIP). Part II: immunization of adults. MMWR Recomm Rep 2006;55(RR-16):1-33.

24. Oliveira LC, Pontes JP. Frequency of hepatitis B immunity and occupational exposures to body fluids among Brazilian medical students at a public university. Rev Inst Med Trop Sao Paulo. 2010;52:247-52.

25. Patterson JM, Novak CB, Mackinnon SE, Ellis RA. Needlestick injuries among medical students. Am J Infect Control. 2003;31:226-30.

26. Reis JMB, Lamounier Filho A, Rampinelli CA, Soares ECS, Prado RS, Pedroso ERP. Training-related accidents during teacher-student-assistance activities of medical students. Rev Soc Bras Med Trop. 2004;37:405-8.

27. Riente KBC, Tsuguta EN, Barbosa SRBS, Zaparoli MA. Avaliação da cobertura vacina contra Hepatite B em 15 municípios da região metropolitana oeste de São Paulo. BE CVE. 2012;2:162-73. [cited 2012 Oct 9]. Available from: http://www.cve.saude. sp.gov.br/boletim/pdf/bol1012.pdf

28. Rossato EM, Ferreira J. Acidentes com perfurocortantes e cobertura vacinal contra hepatite B entre trabalhadores da Saúde no Município de Santa Rosa, Estado do Rio Grande do Sul, Brasil, 2008. Epidemiol Serv Saúde. 2012;21:487-96.

29. Silva FAG, Guedes EA, Miasato JM. Prevalência da vacinação contra hepatite B de graduandos em Odontologia do UNIFESO/RJ. Arq Odontol. 2009;45:117-21.

30. Silveira MB, Perez DA, Yamaguti A, Saraiva EZ, Borges MG, de Moraes-Pinto MI. Immunization status of residents in pediatrics at the Federal University of Sao Paulo, Brazil. Rev Inst Med Trop Sao Paulo. 2011;53:73-6.

31. World Health Organization. Prevention \& Control of Viral Hepatitis Infection: Framework for Global Action. 2012:1-28. [cited 2012 Sep 12]. Available from: http://www.who. int/csr/disease/hepatitis/Framework/en/index.html

Received: 28 January 2013

Accepted: 13 January 2014 